3. Федатов Л.Н. Соціологія масової комунікації : навчальний посібник. Київ : Наукова думка, 2003. 289 с.

4. Фрумкина Р.М. Психолингвистика : учебное пособие. Москва : Academia, 2001. 320 с.

5. Remarks by the President at Campaign Event : вебсайт. URL: https://www.whitehouse.gov/the-pressoffice/2012/05/23/remarks-president-campaign-eventRemarks by the President at Campaign Event (дата звернення: 18.08.2019).

6. Remarks by the President at campaign-event in Mt. Vernon, IA : вебсайт. URL: https://www.whitehouse.gov/ the-press-office/2012/10/17/remarks-president-campaign-event-mt-vernon-іа (дата звернення: 10.11.2021).

7. Remarks of President Barack Obama Weekly Address : вебсайт. URL: https://www.whitehouse.gov/the-pressoffice/2011/12/16/weekly-address-honoring-those-who-served-iraq-war-comes-end (дата звернення: 11.11.2021).

8. Romney M. Remarks in Manchester Following the New Hampshire Primary : вебсайт. URL: http://www. presidency.ucsb.edu/ws/?pid=98865 (дата звернення: 18.08.2019).

9. Romney M. Remarks in Portsmouth, Ohio : вебсайт. URL: http://www.presidency.ucsb.edu/ws/?pid=115592 (дата звернення: 18.08.2019).

10. Romney M. Remarks in Columbia Following the South Carolina Primary : вебсайт. URL: http://www. presidency.ucsb.edu/ws/?pid=99143 (дата звернення: 18.08.2019).

11.Simpson P. Stylistics: A Resource Book for Students. Psychology Press, 2004. 247 p.

УДК 81'23:81'25

DOI https://doi.org/10.32782/tps2663-4880/2021.19.2.2

\title{
ON THE ISSUE OF THE CHALLENGES OF TRANSLATING BUSINESS DISCOURSE (EXTRALINGUISTIC ASPECTS)
}

\section{ЩОДО ПИТАННЯ ПРО ТРУДНОЩІ ПЕРЕКЛАДУ ДІЛОВОГО ДИСКУРСУ (ЕКСТРАЛІНГВІСТИЧНІ АСПЕКТИ)}

\author{
Pylypiuk K.M. \\ orcid.org/0000-0003-0883-351X \\ PhD, \\ Assistant professor at the Department of Philology \\ State Institution "Odessa National Maritime University"
}

\begin{abstract}
The article is dedicated to the study of the non-verbal communicative means in the aspect of translation, in particular strategies, tactics and devices of rendering non-verbal elements of speech etiquette while translating business discourse. The theoretical grounding for the article was formed by the works by Ukrainian and foreign scholars in the field of intercultural communication. In the course of the research there have been investigated the peculiarities of the structure, semantics and functioning of the non-verbal elements of speech etiquette. It has been proved that the incorrect interpretation of gestures, poses, look, clothes by the representatives of different cultures may result not only in the cultural and communicative barrier but also in the total failure. The research has been carried out on the basis of the scripts of business talks and conferences in English and their Ukrainian translations.

It has been revealed that the dominant strategy in rendering non-verbal communicative means in translating English business discourse into Ukrainian is the strategy of re-addressing, relying on which the translator chooses translation tactics and devices. The choice of the strategy is connected with the relevance of the achievement of the communicative goal of the audience's persuasion in this type of discourse. The leading role among the tactics is given to the tactic of rendering relevant information, tactic of linguistic and cultural adaptation and tactic of correct information presentation. The most recurrent translation devices are descriptive translation and contextual replacement. The perspective is seen in the more detailed analysis of each variety of non-verbal communicative means in the aspect of their rendering in translation into other languages.
\end{abstract}

Key words: nonverbal communication, business discourse, speech etiquette, speech communication, proxemics, chronemics, kinesics, translation strategies, tactics, devices.

Статтю присвячено дослідженню невербальних засобів комунікації в аспекті перекладу, зокрема вивченню стратегій, тактик і прийомів відтворення невербальних елементів мовленнєвого етикету під час перекладу ділового дискурсу. Теоретичним підґрунтям слугували досягнення вітчизняних і зарубіжних дослідників у сфері міжкультурної комунікації. Під час дослідження вивчено особливості структури, семантики та функціонального призначення невербальних елементів мовленнєвого етикету. Доведено, що неправильна інтерпретація жестикуляції, пози, погляду, одягу представниками різних культур може призвести не тільки до створення культурно-комунікативного бар'єру, а й до повної комунікативної невдачі. Дослідження провадилось на матеріалі транскриптів ділових перемов і конференцій англійською мовою та їх перекладів українською. У процесі дослідження визначено закономірності, які дозволили сформулювати основні висновки. Ураховано надбання науковців у розвідках за зазначеною тематикою. 
3'ясовано, що провідною стратегією у відтворенні невербальних комунікативних засобів у перекладі англомовного ділового дискурсу українською мовою є стратегія переадресації, відповідно до якої перекладач обирає тактики і прийоми перекладу. Вибір цієї стратегії пов'язаний із вирішальною роллю досягнення комунікативної мети в цьому виді дискурсу. Серед тактик головне місце посідають тактика передання релевантної інформації, тактика лінгвокультурної адаптації і тактика коректного оформлення інформації. Серед перекладацьких прийомів найбільш розповсюдженими виявились описовий переклад та контекстуальна заміна. Дослідження має подальшу перспективу. Перспектива вбачається в більш детальному аналізі кожного окремого різновиду невербальних комунікативних засобів в аспекті їх відтворення у перекладі на матеріалі інших мов.

Ключові слова: невербальна комунікація, діловий дискурс, мовленнєвий етикет, проксеміка, хронеміка, кінесика, перекладацькі стратегії, тактики, прийоми.

Introduction. Today, all human relationships are based on communication. As you know, there are a lot of types of communication. However, the manifestation of non-verbal elements of communication in the situation of communication between representatives of two different cultures - English and Ukrainian - is of particular interest. The interdisciplinary nature of non-verbal communication is due, first of all, to the fact that the very concept of "communication" is universal and is included in the scientific circulation of representatives of most natural and socio-humanitarian disciplines. For example, from a sociological point of view, communication is "the transfer of one or another content from one consciousness to another by means of signs", within the framework of psychological sciences communication should be considered as a "specific form of interaction between people in the process of their cognitive and labor activities". The theoretical basis was the intelligence of well-known scientists associated with non-verbasal communication, in particular: N.D. Arutiunova [1], I.N. Gorelov [2], M.L. Knapp [3], A.A. Leontiev [4], T.A. Orlova [5], J. Rancier [6], A.P. Sadokhin [7], V.I. Sobolev [8].

Problem-setting. The research is focused upon the peculiarities of rendering non-verbal elements in translating English business discourse into Ukrainian. The task is to outline the prominent translation strategies, tactics and operations including transformations at work. The urgency of the study is predetermined by its focus on the underinvestigated parameters of business discourse translation, in particluar means of rendering non-verbal elements of business etiquette. The novelty of the research is in an attempt to perform an overall study of the non-verbal peculiarities.

The objective is formulated as the outline of the specificity of the non-verbal communicative means in English business culture and the ways of their adequate rendering in Ukrainian translation. In order to achieve the goal the following steps have been taken: to determine the features of non-verbal communication as an important element of human speech interaction; to determine the relationship of non-verbal communication with other communicative means; to highlight the main components of non-verbal communication; to characterize paralinguistic units of non-verbal communication; to determine such aspects of non-verbal communication as proxemics, chronemics and kinesics; to analyze different gesture classifications.

Materials and methods of research. The research was carried out on the basis of the tapescripts of business negotiations and conferences in English and their translations into Ukrainian. In the course of the research the following methods were employed: the method of sampling processing, the method of systematization and generalization, methods of contextual and comparative analysis, methods of analysis and synthesis were used.

Findings. It should be noted that psychologists involved in the study of non-verbal communication adhere to the conclusion that non-verbal communication contains all the factors of a person's self-expression not grounded by words.

According to their observations, reading non-verbal code is achief pre-requisite of relatively efficient communication [3, p. 152]. Non-verbal communication is defined by psychologists as a general term including all the aspects of communication realized without the employment of speech means. Gestures, body language, eye contact, factors of the context, predictions etc. All the enumerated means fall into the sphere of the communication system components, transmitting information without the employment of the purely linguistic units. This definition proves a close relationship of non-verbal communication with such sciences as kinesiology, paralinguistics, proxemics. One of the most detailed definitions of non-verbal communication, in our opinion, is the definition by A.A. Leontiev: "Non-verbal communication is not a linguistic communication with non-verbal components" [4, p. 143].

A.P. Sadohin under non-verbal communication in science understands a set of non-linguistic means, symbols and signs, used to transmit information and messages in the process of communication [7, p. 158].

M.S. Andrianov gives the following definition: "Non-verbal communication is a set of non-speech communicative means - a system of gestures, signs, 
symbols, codes used to transmit messages with a high degree of accuracy, which play a crucial role in understanding each other" [1, p. 12].

Non-verbal communication complements the verbal message: if a person smiles and says: "Dear Ladies and Gentlemen", these two actions complement each other. The complement indicates that non-verbal elements make the language more expressive, explain and refine it. A smile, when a person greets the audience, also complements the language message. If a language is accompanied by gestures it is better understood.

Non-verbal behavior also often contradicts language messages: if you do not look into the eyes of your interlocutor and say: "It is very nice to talk to you", such a non-verbal action indicates the refutation of your positive verbal message. Refutation means that non-verbal behavior contradicts a person's words. If you say that you are happy to talk to someone, but at the same time you are so gloomy, you are aloof and reserved, the interlocutor will surely doubt your sincerity.

Non-verbal behavior can also refute what has been said (this can happen due to the spontaneity and unconsciousness of such behavior as a result of the insufficient consciousness control). There are cases when people try to control their non-verbal reaction, but despite this, after a while, it's anyway possible to detect their true state.

Verbal messages can also be replaced by non-verbal acts. For example: a person points at a chair instead of saying, "Sit down, please". In verbal interaction non-verbal actions may act as regulators. Regulation is inderstood as the employment of non-verbal signs to coordinate the interaction between the communicants.

Substitution is when a non-verbal message is used instead of the verbal one. When in public, it is quite possible to indicate to someone with gestures that they are invited to go out and talk.

To support a conversation, there are often used signs that can replace words, for example: gestures, changing posture, touching someone, etc. For example, the nod of the head, the gaze, the intonation or the body langauge can be the signs that it someone's turn to join the conversation. Non-verbal action can repeat the verbal message. For example, the request "Please speak quieter", accompanied by the index finger pressed to the lips.

Non-verbal communication is used to express one's thoughts, feelings, emotions more fully, more accurately and clearly. This is common to all cultures, although different non-verbal signs are not identically interpreted in different cultures. Therefore, it's essential to have a command of non-verbal means of communication, peculiar for the particular culture, if you want to succeed in communication with its representatives [2, p. 238].

The value of non-verbal means of communication for participants in business communication is determined by the importance of the functions they perform. Firstly, the basis of non-verbal communication is formed by the information exchanged by interlocutors without the use of words, that is, non-verbal means perform the function of substitution or complementation of the language means. Secondly, non-verbal means of communication express the emotional states of business interlocutors. Thirdly, they serve to enforce and refine the understanding of the content of verbal communication. Fourthly, they are employed to maintain the optimal level of the emotional aspect of business communication. Fifthly, they demonstrate the status and role positions of interlocutors. And finally, they enhance the effect of the use of verbal means of communication in the process of business communication [8, p. 54].

Let's study the classification non-verbal elements types:

1. Kinesic means of business speech:

- expressive movements (gestures, facial expressions, posture, gait);

- eye contact (direction of the view, the duration of the contact or pause, the frequency of the contact).

2. Prosodic and extralinguistic means (intonation, loudness, timbre, pauses, sighing, laughing, crying, coughing).

3. Tactile (handshake, kiss, applause).

4. Proxemic (distance, proxemity).

Personal distance plays the most important role in the process of interpersonal communication. It is a personal space in which a person does not let others. In English culture, there is even a special word "privacy" to refer to this most important cultural value.

For Ukrainians, compared to the British, personal space is minimal and barely goes beyond the body.

The zone of personal autonomy, the observance of which is mandatory, is manifested in the daily life of the British. When observing their behavior (in transport, on the street, in the store), there is a feeling that "privacy" is not even an abstract concept, but an objective reality, invisible to the naked eye.

It seems that there is a field around each person, which repels strangers from each other, as soon as they get too close, as a result of which people in the crowd collide, if such a nuisance still happens, they sincerely and in detail apologize.

Ukrainians are so tolerant of touch (on the street, in transport, store) that in such situations they do 
not always consider it necessary to apologize. The presence of a zone of privacy among the British and its absence among Ukrainians is manifested in the fact that the British, when walking, try to avoid a collision. While Ukrainians usually apologize in case of direct physical collision or almost encounter, the British apologize when accidentally prespassing somebody's zone of autonomy. At the same time, both subjects apologize, regardless of who provoked the situation.

The difference in the use of space by the British and Ukrainians indicates that the former feel comfortable with more personal space than the latter. The British prefer to stand or sit at a more significant distance from each other than the Ukrainians. Therefore, you shouldn't be surprised if you are moved aside on the oublic transport, or when entering the office of an official for a business meeting, you will be offered to sit somewhere right at the door. It is quite difficult for a Ukrainian person to maintain a conversation in such a situation.

The distance of communication also affects the use of tactile communication signs. The British avoid physical contact in communication, which is not surprising: touching the interlocutor, patting him on the shoulder at a distance of an outstretched hand is difficult and inconvenient. The British do not hug, kiss, or touch each other. Even such a common gesture of greeting as a handshake is used only when meeting someone for the first time. Moreover, the handshake of the English is shorter, it is done with a fully outstretched hand and without trying to hold the interlocutor's hand in yours.

Gestures and facial expressions in English culture are used very limitedly. And this is natural: the greater the distance characteristic of a particular culture is, the more norms and restrictions on human behavior there are in it. Limited gestures, as well as restrained, non-intensive facial expressions, are a sign of education and good manners.

You should also pay attention to the use of eye contact. As well as in other European cultures, a direct stare is a sign of attention and interest for the British. In this case, the eyes are usually motionless, do not switch from object to object, but are focused at one point. To make it clear to the interlocutor that they hear and understand him, the British often do not nod their heads, but blink. At the same time, it is not accepted to look directly into the eyes of the interlocutor.

In Ukrainian culture, which researchers call "staring", compared to Anglo-Saxon culture, the custom of looking directly into the eyes means sincerity, which indicates a direct relationship between eye contact and frankness in relationships.
Ukrainians use gestures much more often: they nod their heads as a sign of consent; they shake their heads when they disagree; they shrug their shoulders or spread their hands when they say "I don't know". Gestures have a greater amplitude than in Western European cultures, and take up more space.

Significant differences in the behavior of the British and Ukrainians are manifested in a smile that has a great national originality. In English culture, a smile is a mandatory element of communication, while one of the most striking and nationally specific features of Ukrainian non-verbal behavior and communication in general is, as the researchers note, "domestic insinuity" [6, p. 67-74].

If we do not take into account dialogue speech, non-verbal support of oral speech, it can lead to the distortion of the picture of real communication. Dialogue language, as a reflection of the communicative process, cannot be exempt from the semantics of gestures, movements, facial expressions, intonation and other means that reflect the non-verb support of oral speech [5, p.51].

The undoubted interest for this research and in general for the consideration of the English-language text in the course of business communication is the fact that non-verbal semiotics are formed by numerous sciences:

1) paralinguistics is the science of sound codes of non-verbal communication;

2) kinesics is the science of sign phenomena and gestures in general;

3) oculesics is a part of paralinguistics that deals with eye movements and views;

4) auscultation is the science of auditory perception of sounds and listening behavior of people in the process of communication;

5) gaptics is the science of the language of touch and tactile communication;

6) gastics is the science of iconic and communicative functions of food and drinking;

7) olfaction is the science of the language of smells and their role in communication;

8) proxemics is the science of communication space, its structure and functions;

9) chronemics is the science of communication time, its structural, semitic and cultural functions.

Non-verbal sources of information are realized on the sheet by verbal markers - components of the value-semantic space of the language, which in the process of indirect communication makes the situation more realistic. The need to establish patterns of transcoding verbal markers of non-verbal communicative code in intercultural adaptation is due to the fact that non-verbal sources of infor- 
mation are of social origin, so intercultural differences in the nominative field of culturally labeled concepts appear in them especially vividly, which causes many problems of intercultural direct communication and, especially, when creating conditions for intercultural indirect communication, that is, in the process of translation.

All the variety of components of non-verbal information code is classified by A.P. Sadokhin in the following way.

Kinesics is a set of gestures, poses, body movements that are used in communication as additional means of expression of communication. Tacesics comprises handshakes, kisses, stroking, patting and other touches to the partner's body in communication. Sensorics is a set of sensory perceptions based on information from the senses. Proxemics includes different ways of usinh space in the process of communication. Chronemics is the use of time in communication [7, p.156].

Kinesics includes visual perception of movement, performs a regulatory function in communication. These are not only the movements of the face and body, but also the design of appearance, gait, handwriting, etc.

To study communication with the help of the enlisted non-verbal components of information, the term "kinema" was proposed as the smallest unit of non-verbal code, reading which can be interpreted through gestures and other movements.

Gestures are various kinds of movements of the body, hands, hands, which accompany in the process of direct communication human language and express the attitude directly to the interlocutor.

Gestures used in all cultures can be divided into arbitrary and involuntary, culturally conditioned and physiological. Most of the gestures are culturally conditioned. Thus, gestures-illustrators are descriptive-figurative and expressive gestures that accompany the language, characterize speech in more detail [8, p. 157]. Tacesics combines such non-verbal sources of information as handshakes, kisses, stroking, patting and other touches to the interlocutor.

However, in the business sphere, only one type of body contact is accepted - a handshake. In the form of a handshake more often than when using other non-verbal means, status differences between the parts are revealed. According to this feature, there are three forms of handshake:

1) the hand on top, the palm turned down. This action indicates the desire for dominance of the one whose hand it is;

2) hand bottom, palm turned up. This handshake reflects the position of obedience;
3) palms in the same vertical position. This form of handshake stands up for the equality of interlocutors.

In the case of close relations between business partners and equality of their statuses, it is possible to pat on the shoulder.

Proxemics is a set of proxemes, that is, ways to use space in the process of communication.

Space distance serves as an indicator of status-role differences between participants in business communication. The distance between partners with the same statuses is closer than the distance between employees who are in different positions in the status hierarchy.

Sensorics is a segment of non-verbal communication code, combining a set of information from the human senses.

Chronemics is a segment of non-verbal communication code, uniting chronems, that is a set of ways to use time in the process of communication.

Conclusions. Thus, the study of the process of adaptation of verbal markers of kinemes, tacemes, sensemes, proxemes and chronemes as components of non-verbal code of information of culturally colored concepts forming the value-semantic space of speech, established a different degree of their adequacy to the invariant.

It was found out that the leading strategy in the reproduction of non-verbal communicative means in the translation of English business discourse into Ukrainian is the strategy of re-addressing, according to which the translator chooses translation tactics and techniques. The choice of this strategy is predetermined by the decisive role of the communicative objective in this type of discourse: the success of the agreements, the achievement of consensus, the signing of the agreement.

Among the tactics, the main place is occupied by the tactics of transmitting relevant information, which is manifested in the form of reproduction of only important extralinguistic information by language means of translation, tactics of linguistic adaptation, the observance of which is a successful means of avoiding communicative conflict and tactics of the correct registration of information. Among the translation techniques, descriptive translation and contextual replacement are the most common. When analyzing video scripts, lexical material formed by verbalized matches of movements, gestures, kinemes, proxemes, etc. was taken as a basis. The perspective is seen in a more detailed analysis of each individual variety of non-verbal communicative means in terms of their reproduction in translation on the basis of other languages. 


\title{
REFERENCES:
}

1. Арутюнова Н.Д. Предложение и его смысл: логико-семантические проблемы. Москва, 1976. 388 с.

2. Горелов И.Н. Невербальные компоненты коммуникации. Москва, 1980. 238 с.

3. Кнапп М.Л. Невербальные коммуникации. Москва, 1978. 308 с.

4. Леонтьев А.А. Психология общения., 1999. Москва, 365 с.

5. Орлова Т.А. Информативные ресурсы недиалоговой части англоязычного драматического текста (на материале пьес американских авторов XX века). Самара, 2007. 245 с.

6. Рансьер Ж. Несогласие: Политика и философия. Санкт-Петербург, 2013. С. 67-74

7. Садохин А. П. Межкультурная коммуникация : учебное пособие. Москва, 2004, С. 158.

8. Соболев В.И. О деловом этикете, и не только... Нижний Новгород., 2013. 588 с.

\section{ОСОБЛИВОСТІ ПЕРЕКЛАДУ РЕКЛАМНИХ СЛОГАНІВ СФЕРИ ХАРЧУВАННЯ З НІМЕЦЬКОЇ МОВИ НА УКРАЇНСЬКУ}

\author{
FEATURES OF TRANSLATION OF ADVERTISING SLOGANS \\ IN THE NUTRITIONAL SPHERE FROM GERMAN INTO UKRAINIAN
}

\author{
Підлужна I.A., \\ orcid.org/0000-0003-2720-804X \\ старший викладач кафедри філології, перекладу та стратегічних комунікачій \\ Національної академії Національної гвардії України
}

\begin{abstract}
Статтю присвячено вивченню особливостей перекладу рекламних слоганів сфрери харчування з німецької мови на українську. Автором визначено основні лінгвостилістичні характеристики німецькомовних рекламних текстів. Досліджено проблеми перекладу рекламних слоганів із німецької мови на українську. Описано особливості композиційної структури рекламного тексту та акцентується увага на взаємозв'язку його вербальних і невербальних компонентів. Матеріалом дослідження слугували рекламні повідомлення і слогани, виокремлені з німецькомовного рекламного середовища.
\end{abstract}

Автором досліджено специфіку рекламних німецьких текстів, визначено основні структурні елементи рекламного тексту. Основними групами лексичних засобів впливу, які характеризують рекламу продуктів харчування, $€$ емоційно-експресивна лексика, спеціалізовані терміни, займенники першої та другої особи, а також різноманітні стилістичні прийоми.

Автор розкриває основні стратегії, які використовуються для перекладу рекламного тексту. Аналізує різні засоби перекладу рекламних слоганів у сфері харчування та доцільність використання лексико-семантичних трансфрормацій.

Автор дійшов висновку, що складність, яка виникає під час перекладу слогана, є збереженням комунікативного наміру реклами. Вибір варіанта перекладу повністю залежить від рівня комунікативної компетентності перекладача і його трансляційних уподобань. Під час перекладу німецьких рекламних текстів необхідно орієнтуватися на досягнення динамічної еквівалентності. Завдання перекладача - зуміти зберегти та передати імідж товару і його вербально-візуальне оформлення. Визначальною рисою створення міжкультурної реклами $є$ її прагматичне значення, оскільки мета рекламного слогана - заохотити потенційного споживача купити товар.

Одержані результати дозволять дослідити та обґрунтувати процес та стратегії перекладу рекламних слоганів, що дає змогу більш точно та зрозуміло донести до реципієнта інформацію, закладену в оригінальному тексті.

Ключові слова: рекламний текст, слоган, рекламний відеоролик, еквівалент, інтернет-реклама.

The article is devoted to the study of the features of the translation of advertising slogans in the nutritional sphere from German into Ukrainian. The author identifies the main linguistic and stylistic characteristics of German advertising texts. The problems of translation of advertising slogans from German into Ukrainian are investigated. The features of the compositional structure of the advertising text are described and the attention is focused on the interrelation of its verbal and non-verbal components. The material of the study were advertising messages and slogans taken from the Germanspeaking advertising environment.

The author investigates the specifics, features of advertising German texts, identifies the main structural elements of advertising text. The main groups of lexical means of influence that characterize the advertising in the nutritional sphere are emotionally expressive vocabulary, specialized terms, first and second person pronouns, as well as various stylistic devices.

The author reveals the main strategies used to translate advertising texts, analyzes various means of translating of advertising slogans in the nutritional sphere and the feasibility of using lexical and semantic transformations. 